\title{
A SZAKMAKÖZI EGYÜTTMÜKÖDÉS LEHETŐSÉGEI A SZOLNOKI KISTÉRSÉGBEN EGY CSALÁDON BELÜLI ERŐSZAK KUTATÁS TÜKRÉBEN ${ }^{1}$
}

\author{
(The Possibilities of Interprofessional Cooperation \\ in the Micro-Region of Szolnok in Connection with a Research \\ on Domestic Violence)
}

\section{JÁSZ KRISZTINA - SZARVÁK TIBOR}

\begin{abstract}
Kulcsszavak:
szakmaközi egvüttmüködések kistérségi szociális tervezés családon belüli konfliktusok társadalmi szerepek

A családon belüli eröszak olyan negativ társadalmi jelenség, amely élénken foglalkoztatja a közvéleményt, fokozott hirértékkel bir a médiában, vitákat generál a politika, a jogalkotás és a közvélemény szintjén egyaránt. A kutatási program egyes elemeinek végrehajtása érzékelhetôen erösitette a rendörkapitányság szakemberei és a szociális munkások közötti együttmüködést, javitotta az intézmények közötti kommunikációt. Kialakultak azok a személyes kapcsolatok, amelyek elengedhetetlenek a gyors és összehangolt közös cselekvéshez.
\end{abstract}

A családon belüli erőszak egyike napjaink legsúlyosabb társadalmi problémáinak, amelynek kutathatóságát, objektív feltárását nagymértékben nehezíti a jelenséget jellemző nagyfokú látencia. A segítségkérés gyakori elmaradása korlátokat szab a preventív intézkedések alkalmazásának is.

Az ilyen típusú eröszakos jogsértések jelentős hányada olyan egyének között valósul meg, akik egymással szoros érzelmi, erkölcsi és anyagi függésben élnek. A probléma össztársadalmi szinten történő kezelését nehezíti az a körülmény is, hogy a közvélemény nagyobbik hányada még mindig a magánszféra részének tekinti az ilyen típusú cselekedeteket, és az egyén felelösségét hangsúlyozza a veszélyeztető helyzet kialakulása, majd késỏbbi feloldása kapcsán is.

Mielött rátérnénk a családon belüli erőszak legfontosabb ismérveinek összefoglalására, érdemes áttekintenünk családszociológiai szempontból a család, mint társadalmi kőzősség alapvetô sajátosságait.

A változó emberi viszonyok közepette is tartja magát az az állítás, hogy az emberi társadalmakban megtalálható intézmények közül a legfontosabb a család. Ez elsösorban annak köszönhetö, hogy az adott társadalom számára meghatározó fontosságú funkciókat lát el. Minden, ami egy adott családban lezajlik egyszerre formálója, és megjelenítője az adott családot jellemző kapcsolat- és viszonyrendszernek, valamint alakítja az adott közösség beágyazódását is. 
Jász Krisztina - Szarvák Tibor: A szakmaközi együttmüködés lehetöségei a szolnoki kistérségben egy családon belüli erőszak kutatás tükrében. - Tér és Társadalom, 21. 2007. 2. 67-84. p.

A család a privát szféra legintimebb területe, a családtagok között kialakult szerepek, az egymáshoz és a külvilághoz való kapcsolódást meghatározó viszonyrendszer az intézményeken keresztül történő társadalmi beavatkozás számára - első közelítésben - érinthetetlen közegnek tekintendö. Amennyiben azonban a családban diszfunkcionális müködésből származó zavar keletkezik, az adott esetben a társadalom egészét veszélyeztetheti. Ezen diszfunkcionális müködés egyik megnyilvánulási formája a családon belüli erőszak, amely nagyon sokrétü jelenség.

A következökben elsősorban Ranschburg Jenő A meghitt eröszak (2006) címü munkája alapján foglaljuk össze a családon belüli erőszak legföbb ismérveit.

A pszichológia a családon belüli erőszaknak három megnyilvánulási formáját tartja számon, amelyek a következők:

- a házastársak (intim partnerek) közötti,

- a gyermekek elleni,

- a családban élö idős (részben vagy teljes mértékben magatehetetlen) személy elleni erőszak.

Mindhárom típusra jellemzö, hogy az erőszakos cselekmény nem kizárólag fizikai erőszakban ölt testet, hanem szándékosan elöidézett lelki terror is társul hozzá. A fizikai és pszichikai erőszak mellett létezik a családon belüli erőszaknak egy harmadik formája is, a szexuális erőszak, illetve a föként gyermekeket és időseket érintő gondozás, gondoskodás elmulasztása, vagy az ilyen családtagok végzetes következményekkel járó elhanyagolása.

A fentiekben vázolt három típusba sorolható eröszakos cselekedetek közös sajátossága, hogy azonos a dinamikájuk. Mindegyik esetre egyaránt igaz ugyanis, hogy a családon belüli eröszakot elkövető személy nem megfelelő módon alkalmazza testi erejét, hatalmát és az ehhez kapcsolódó irányítási lehetőségeit. Ezért nagy valószínüséggel megjósolható, hogy azokban a családokban, ahol az erőszak egyik fentiekben jelzett - típusa jelen van, ott hamarosan tanúi lehetünk az eröszak más típusú megjelenésének is.

Léteznek olyan kockázati faktorok, amelyek egy-egy családban való jelenléte jelentősen megnövelheti a családon belüli erőszak előfordulásának valószínủségét is. Ezek a következök:

- szociokulturális hagyományok,

- alkohol- és drogfüggőség,

- kedvezőtlen anyagi helyzet,

- féltékenység,

- érzelmi elhidegülés,

- az erőszak előfordulása valamelyik családtag saját korábbi családjában,

- az erőszakra vonatkozó szociális attitüdök (vélemények, hiedelmek),

- bizonyos gyakorlati tevékenységek, például lőfegyver jelenléte a lakásban.

Családon belüli erőszakról akkor beszélünk egy adott közösségben, ha megvalósul a kényszer valamely formája, a fizikai bántalmazás, valamint a rendszeresen 
Jász Krisztina - Szarvák Tibor: A szakmaközi együttmüködés lehetöségei a szolnoki kistérségben egy családon belüli erőszak kutatás tükrében. - Tér és Társadalom, 21. 2007. 2. 67-84. p.

TÉT XXI. évf. 20072 A szakmaközi együttmüködés lehetöségei a ...

69

ismétlődő, valamely családtag által szándékosan előidézett tartós lelki gyötrelem. Az erószaknak ez a megnyilvánulási formája is általában tanult viselkedés.

A családon belüli erószaknak, csakúgy, mint számos más búncselekménynek, sajátos anatómiája van. A szakirodalom szerint minden bántalmazási folyamatot három, jól elkülöníthető szakaszra tagolhatunk:

- a feszültség felgyülemlésének szakasza,

- az eröszak kitörése,

- valamint a megbánás szakasza, a ,nászút periódus” (Walken - idézi Nagy 2005).

Az erószak fentiekben vázolt ciklusai időről időre megismétlődnek, gyakran felgyorsulnak. Az erőszakos cselekedetek a családon belül egyre gyakoribbá válnak. Jellemző továbbá, hogy a harmadik, úgynevezett „megbánó szakasz” az idő előrehaladtával eltünik.

E társadalmi jelenség kapcsán az egyik legfontosabb kérdés az, hogy hogyan végződnek az ilyen típusú erószakos cselekedetekkel megterhelt családi kapcsolatok. $\mathrm{Az}$ esetek többségében négy lehetséges forgatókönyv érvényesül:

- a gyermek kiemelése a családból - ez gyakran egyet jelent a bántalmazó többi potenciális áldozatának magára hagyásával;

- az áldozat lép ki a kapcsolatból - ebben az esetben az érintett leggyakrabban rokonokhoz vagy anyaotthonba menekül;

- a kapcsolat biztonságos befejezése - ilyen esetben az áldozat és az elkövetô is segítséget kap;

- a kapcsolat fennmarad,

- de kezeletlen marad a probléma, ebben az esetben bármelyik fél depresszióssá, esetleg öngyilkossá válhat,

- az erőszak áldozata komoly sérüléseket szenved, szélsóséges esetben partnere meg is ölheti,

- önvédelemből a sértett megölheti bántalmazóját,

- a megfelelő módon kezelik a problémát az ellátórendszer segítségével (NANE 1999 - idézi Nagy 2005).

A legutolsó, mindenki által legmegfelelőbbnek tartott forgatókönyv megvalósítását nehezíti az a körülmény, hogy az esetek többségében az illetékes szakemberek, a jelzőrendszerhez tartozó intézmények munkatársai nincsenek kellően mély és átfogó információk birtokában a bántalmazás elözményeivel, dinamikájával és a lehetséges megoldásokkal kapcsolatban.

Végezetủl fontos arról is említést tenni, hogy a bántalmazott felet mi tartja benn adott esetben a családon belüli erőszakkal érintett párkapcsolatban. Ezek az indokok (a teljesség igénye nélkül) a következők: anyagi függés, a gyerekek, félelem az egyedülléttôl, a szerelem, a hüség, a tagadás, a sajnálat, a kötelességérzet, a korlátozó sztereotípiảk, félelem a partner esetleges öngyilkosságától, a bủntudat, az alacsony önértékelés, a szégyen, a zavar és a megalázottság, valamint a tehetetlenség-érzet és a bizakodás. 
Jász Krisztina - Szarvák Tibor: A szakmaközi együttmüködés lehetöségei a szolnoki kistérségben egy családon belüli erőszak kutatás tükrében. - Tér és Társadalom, 21. 2007. 2. 67-84. p.

70 Jász Krisztina-Szarvák Tibor

TÉT XXI. évf. 2007

A családon belüli eröszak áldozatai zömében nők, gyermekek, valamint más helyzetüknél fogva kiszolgáltatott emberek. Elkövetői oldalon a legnagyobb arányban férfiak állnak, akik elsősorban apai, nevelöapai, házastársi, élettársi, ritkábban más rokoni, gondozói minőségükben követik el az ilyen típusú cselekményeket. Az elmúlt időszakban azonban - valószínủleg szocializációs okok kövekeztében - a nők agresszivitása is számottevő mértékben megemelkedett, és a férfiakkal szemben elkövetett családon belüli eröszak tekintetében is jelentős növekedés következett be (Ranschburg 2006). Ez utóbbi estekben azonban a látencia méginkább meghaladja a nők sérelmére elkövetett erőszakos cselekedetek esetében tapasztalható mértéket, ugyanis a férfiak még kevésbé fordulnak a jelzörendszerhez segítségkérési szándékkal.

Annak érdekében, hogy e sokrétegủ, komplex, számos elöítélettel, nagyfokú látenciával terhelt társadalmi problémával érintettek köre jelentös mértékben csökkenjen a magyar társadalomban, szükség van egy össztársadalmi attitủdváltásra, illetve a kezelésében érintett intézmények közötti tartós és eredményes partnerségi kapcsolatokra.

\section{A kutatásról ${ }^{2}$}

A családon belüli eröszak megjelenési formáira koncentráló kutatásunk két fỏ módszertani elemmel jellemezhető. Alapvetően a Szolnok Városi Rendőrkapitányságnál fellelhetỏ adatforrások alapján a települések családsegitoo- és gyermekjóléti munkatársainak segitéségével kerestük fel az interjúalanyokat ${ }^{3}$. Fontos rögzítenünk, hogy ezért a kérdezési szituáció nem a tipikus kérdezőbiztosi szerepet követelte meg munkatársainktól, hanem kvázi terápiás (kliensi) interjúként is kellett ezt a helyzetet kezelni a részt vevő, segitő szakembereknek. Azért választottuk a segítő szakmák munkatársait, mivel megjelenésük nem kelt okvetlenül gyanút az agreszszorban, ugyanez a rendörséggel kapcsolatban nem mondható el. A kérdezőbiztosok többsége maga is azonosult a kutatás céljaival, és ennek is köszönhetô, hogy viszonylag nagy számban vállalkoztak klienseik a válaszadásra.

Kérdőiveink a lehetséges alapsokaság $24 \%$-át mértek fel. Mivel a válaszadás önkéntes volt, ezért csak leíró jelleggel állapítjuk meg, hogy leginkább a városokban vállalták az interjút a családon belüli eröszak áldozatai.

\section{A minta alapjellemzöi}

Segítő munkatársaink válaszadói túlnyomórészt nök voltak: a 120-ból 111 kérdezett (90\%) tartozik a „gyengébb” nemhez. Ez az arány utal(hat) arra, hogy a családon belüli erószak egyik jellemző felnőttkorú bejelentői elsősorban a nők ${ }^{4}$. Családi állapot szerint azt látjuk, hogy a házasok és az elváltak aránya közel egyforma, 32-30\%.

A minta átlagéletkora 44 év. A harminc év alattiak aránya összesen 16\%, azonban fontos, hogy minden tizedik megkérdezett a nyugdijas korosztályba (60 évnél idösebbek) tartozik. Lényegében mintánk közel harmada az ötvenen túli demográfiai csoportba tartozik. 
Jász Krisztina - Szarvák Tibor: A szakmaközi együttmüködés lehetöségei a szolnoki kistérségben egy családon belüli erőszak kutatás tükrében. - Tér és Társadalom, 21. 2007. 2. 67-84. p.

TÉT XXI. évf. 2007 a szakmaközi együttmüködés lehetőségei a ... 71

A felvétel szerinti átlagos háztartásnagyság 3,38 fỏ volt. A kérdezettek nagy része (47\%) 3 vagy 4 fós háztartásban él, ugyanakkor a 2 fós háztartásban élök aránya is jelentősnek mondható (26\%), míg az 5 vagy több fös háztartások tagjai 21\%-ban vannak jelen a mintában. A városokban az átlagos háztartás-nagyság 3, a községekben 4 fơ.

A konfliktusok megoldásában fontos szerepet játszó iskolai végzettség tekintetében a legmagasabb arányban a maximum 8 osztályt végzettek jelennek meg a mintában $(43 \%)^{5}$. Fontos utalnunk arra, hogy a mintában szintén magas az aránya $(29 \%)$ a szakmunkás illetve szakiskolai végzettségủeknek. Érettségivel minden ötödik válaszadó, diplomával a minta alig 3\%-a rendelkezik.

A kérdezettek 44\%-a folytat valamilyen keresőtevékenységet, 28\%-a inaktív, ezen belül 14\% munkanélküli. Rokkant- vagy öregségi nyugdíjban részesül a megkérdezettek negyede. Feltünó, hogy a válaszadók közötti munkanélküli arány magasabb, mint az országos vagy akár a megyei átlag, a foglalkoztatotti arány viszont elmarad a nemzeti és a területi átlagtól is.

A kérdezettek lakókörnyezetének és lakásviszonyainak mutatói alapján megállapítható, hogy a többségük (57\%) kertes családi házban él, a ,panellakók” a mintában $21 \%$-ot képviselnek. Lepusztult, szegénytelepszerü környezetben csupán $8 \%$ lakik, a többiek átlagos vagy vegyesen, romák és nem romák által egyaránt lakott környéken élnek. A válaszadók közel fele (a kistérség helyzetéből adódóan) szolnoki lakos. Vélhetően ebból az állapotból következik az, hogy a mintába került válaszadók kétharmada a Szolnoki Rendőrkapitányság illetékességi területéhez tartozó városokban lakik.

\section{A társadalmi-települési hálózatok szerepe, jellemzói}

Felmérésünk első önálló fejezetében megdöbbentő (a társadalmi kapcsolati háló gyengeségére utaló) eredményt kapunk: a felsorolt 12 változó közül csak kettő lépte át a 50 pontos határt ${ }^{6}$.

Válaszadóink gondjaik, problémáik megoldásában leginkább a családot ( 100 fokozatú skála átlaga: 54 pont) és a szociális segítőket (100 fokozatủ skála átlaga 60 pont) említették. A bizalom ${ }^{7}$ és a szolidaritás hiányát egyrészt jól jelzi az, hogy a professzionális segítő még a hagyományos támaszt, a családot is megelözi; másrészt az is, hogy a barátokra (100 fokozatú skála átlaga: 41 pont), szomszédokra (100 fokozatú skála átlaga: 31 pont) munkatársakra (100 fokozatú skála átlaga 27 pont) alig számítanak válaszadóink. A helyi polgármesteri hivatalt megjelenítő személyek (ügyintézők, jegyző, képviselö, polgármester) sem számítanak a kapcsolati háló erős „láncszemének".

A családon belüli erőszak kérdésében esetenként preventív és gyógyító szerepet egyaránt felvállaló egyház és a civil szervezetek említése alig jellemzỏ (100 fokozatú skála átlaga 10, illetve 21 pont). Megjegyzendő, hogy minden ötödik válaszadó mondott a problémakörrel foglalkozó szervezeteket, amelyek helyi szinten viszont nem 
Jász Krisztina - Szarvák Tibor: A szakmaközi együttmüködés lehetőségei a szolnoki kistérségben egy családon belüli erőszak kutatás tükrében. - Tér és Társadalom, 21. 2007. 2. 67-84. p.

találhatók meg. 1lyen szervezetek közül a válaszok 75\%-ában a Nők a Nőkért Együtt az Erőszak Ellen Egyesület (telefonos segélyvonalát) szerepelt.

Összességben tehát a hagyományos segítő kapcsolatokra adott alacsony pontszámok a tradicionális, közösségi hálózatok hiányát mutatják. A kirekesztettséget csökkenteni, a társadalmi hálót ,újrakötni” szinte kizárólag a professzionális segítő szféra képes. Ez az adatsor jól mutatja azt, hogy a közösség-építés a családon belüli erőszak nézőpontjából is fontos, egyfajta össznemzeti feladatként is felfogható.

A kérdést a városok és a községek tükrében vizsgálva jelentős különbségek találhatók. A városokban különösen jellemző a családok szerepe ${ }^{8}$, a községekben lakók viszont sokkal jobban számítanak a professzionális segítőkre és a polgármesteri hivatal prominenseire (1.ábra).

\section{1. ÁBRA}

A társadalmi kapcsolati háló jellemzői 100 fokozatú skálán

(The Characteristics of the Network of Social Relations on a 100-grade Scale)

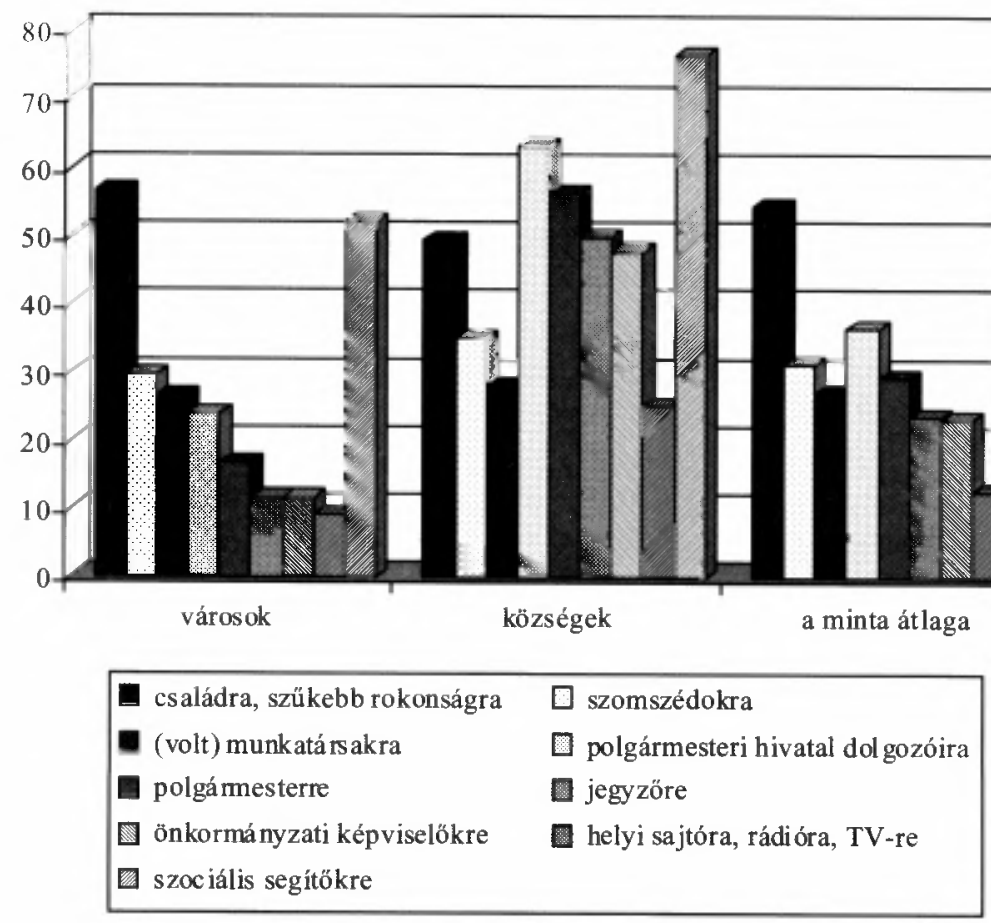

Forrás: Saját szerkesztés.

A korosztályok tükrében azt látjuk, hogy a család és a szociális segítés a fiatal, legalább szakmunkásvégzettséggel rendelkezö felnőttek körében elfogadottabb. 
Jász Krisztina - Szarvák Tibor: A szakmaközi együttmüködés lehetöségei a szolnoki kistérségben egy családon belüli erőszak kutatás tükrében. - Tér és Társadalom, 21. 2007. 2. 67-84. p.

TÉT XXI. évf. 2007 - 2 A szakmaközi együttmüködés lehetóségei a ... 73

A társadalmi kapcsolati háló gyengeségét értelmezhetjük a kockázati társadalom oldaláról is. Ebben a dimenzióban a személyes sors bizonytalanságát és kiszámíthatatlanságát vizsgálhatjuk. Kutatásunkban a rizikótényezőket a hagyományos anómiaskála bővítésével értelmezhetjük.

Mintánk körében két alap-attitüd volt megfigyelhető. Ez egyrészt a jövőképhiány (mondjanak bármit, az emberek zömének egyre rosszabbul megy - 100 fokozatú skála átlaga 82 pont), másrészt az állami gondoskodás igénye (az államnak minden segítséget meg kell adnia, hogy az emberek könnyebben éljenek - 100 fokozatú skála átlaga 84 pont).

Válaszadóink legkevésbé a tudás fontosságát ismerték el (minél tanultabb valaki, annál könnyebben él - 100 fokozatú skála átlaga 56 pont) ${ }^{9}$, s leginkább a közbiztonság miatt aggódtak (az utóbbi években egyre több a bủnözés - 100 fokozatú skála átlaga 91 pont; a hozzánk hasonló embereket manapság több veszély fenyegeti, mint régebben - 100 fokozatú skála átlaga 85 pont). A hivatalokkal szembeni paszszivitás inkább a városokban (különösen Szolnokon) figyelhetö meg. A ,nincs sok értelme a hivatalokhoz fordulni, az átlagember baja nem igazán érdekli őket" elnevezésủ választípus értéke 100 fokozatú skálán Szolnokon 66, a városokban 63, a községekben pedig 56 pont.

A megkérdezettek azonban elismerik azt, hogy „csak az tud boldogulni, aki saját sorsát irányítja" (100 fokozatú skála átlagpontja 70), illetve az összefogás erejét is hangsúlyozzák (az emberek jobban boldogulnának, ha összefognának - 100 fokozatú skála átlagpontja 89).

\section{Normaszegés - normakövetés határán: a családon belüli eröszak különböző kategóriáinak megítélése}

Válaszadóink az általunk említett normaszegésekkel nem szimpatizálnak. Leginkább a potyautas-magatartást fogadják el, a gyümölcslopást és adócsalást elkövetó emberekkel megértők. Ezeket a cselekményeket a makrotársadalom is inkább elnézi és kevésbé szankcionálja. A kérdezettek általában nagymértékben elítélik a családon belüli bántalmazás minden formáját, különösen a fizikai erőszakot. Legsúlyosabb megitélés alá a gyermekelhanyagolás esik.

Hasonlóan a különböző magatartásokkal kapcsolatos lojalitás-értékekhez a büntetési tételek között is a legenyhébbnek a gyümölcslopás és a potyautas cselekedet minösíthető. A családon belüli bántalmazás büntetendőségének megítélése gyakorlatilag egy kategóriába sorolódik az ittas vezetéssel és a kábítószerek kipróbálásával. A bántalmazások köréböl a fizikai erőszakot és a gyermekelhanyagolást gondolják a leginkább, az idős családtagról való gondoskodás elmulasztását a legkevésbé büntetendőnek.

Fontos megemlítenünk, hogy a cselekedettekkel szembeni erösebb tolerancia (lojalitás) inkább a városi (föként a szolnoki); a 34 évesnél fiatalabb válaszadókat 
Jász Krisztina - Szarvák Tibor: A szakmaközi együttmüködés lehetöségei a szolnoki kistérségben egy családon belüli erőszak kutatás tükrében. - Tér és Társadalom, 21. 2007. 2. 67-84. p.

74 Jász Krisztina-Szarvák Tibor

TÉT XXI. évf. 2007 2

jellemzi. A büntethetőségi skálán viszont elsősorban a városi (alapvetően szolnoki) megkérdezettek válaszai mutattak erósebb intenzitást.

A válaszadói közvélekedésben a családon belüli viszonyokban a verbális erőszak $^{10}$ a magánszférát érinti ( 100 fokozatú skála átlaga: 60 pont). A konkrét erőszak megjelenése közül a gyermek pofozása már nem tartozik egyértelmủen a magánügy kategóriába (100 fokozatú skála átlaga: 48 pont). Válaszadóink szerint beavatkozni a szexuális zaklatás, a házastárs, valamint a szülő verés, illetve az idős vagy (és) magatehetetlen családtag elhanyagolása terén kell leginkább. Összességében a verbális erőszakot leszámítva a bántalmazás összes formáját kevesebben tekintik magánügynek, inkább a beavatkozást gondolják szükségesnek. Fontos megjegyeznünk, hogy a férfiak (bár mintánkban kevésbé vannak reprezentálva) kevésbé tünnek beavatkozás pártinak.

A magán és a közérdek határának megítélésében a fiatal felnőttek (34 évnél fiatalabbak) megengedőbbek. Körükben inkább magánügynek tartják a verbális erőszakot, a gyermek fizikai bảntalmazását. Megjegyezzük, hogy a férj bántalmazó, erőszakos cselekedeteinek és az idős vagy magatehetetlen családtag elhanyagolásának megítélésében a válaszadók között ebben a demográfiai körben a leggyengébb a beavatkozás igénye.

Valószínüleg a szocializációban rejlő tradíció köszön vissza abban, miszerint a gyerek nevelö célzatú verése fontos elem a szülói gondoskodásban. Ezt mutatja az az adat is, mely szerint a gyerek verését a vizsgálati személyek sokkal inkább magánügynek tekintik, mint az összes többi tételt.

A településtípusonként eltérő közösségi, együttélési normákra; a professzionális segítés beavatkozási dilemmáira utal az a szignifikáns különbség, amit akkor látunk, ha a kérdést a városok és a falvak összefüggésében vizsgáljuk. Azt tapasztaljuk, hogy a falvakban minden vizsgált kategóriát inkább a magánszféra irányába tolnak el. Tulajdonképpen a városok között is inkább Szolnok az, amelyik beavatkozás-pártinak tekinthető. Ennek ellenére (vagy talán éppen ezért) a községekben élök fontosabb kérdésnek tartják napjaink Magyarországán a családon belüli erőszak kérdését (100 fokozatú skála átlaga: 95 pont) ${ }^{11}$. Általánosan elfogadottnak tartják azt is, hogy a családon belüli eröszak a családban lévő gyermek testi-lelki fejlödését, egészségét súlyosan veszélyezteti.

\section{Bántalmazások a mindennapokban - a családon belüli eröszak anatómiája}

A kérdezettek véleménye szerint a családi veszekedések leggyakoribb okai az italozó életmód, a szegénység (anyagi gondok) és a türelmetlenség lehetnek. A kapcsolati, érzelmi tényezőket (szexuális élet, szerelem, gyakori távollét) valamint a párok gyermekneveléssel kapcsolatos konfliktusait az előbbieknél kevésbé jellemző momentumoknak tartják válaszadóink. 
Jász Krisztina - Szarvák Tibor: A szakmaközi együttmüködés lehetöségei a szolnoki kistérségben egy családon belüli erőszak kutatás tükrében. - Tér és Társadalom, 21. 2007. 2. 67-84. p.

TÉT XXI. évf. 2007 — A szakmaközi együttmüködés lehetöségei a ... 75

A kérdés szintetizálására egy matematikai eljárást, a fökomponens-analízist is segítségül hívtuk $^{12}$. A válaszadók a veszekedés-okok körében három jól körülhatárolható jellemzőt állítottak fel (a három komponens az adatok 64\%-át örizte meg). A legnagyobb magyarázóerővel (36\%) bíró szegmens az érzelmi konfliktusforrás (a faktorsúlyok alapján ide tartozó változók: a türelmetlenség, elmúlik a kapcsolatból a szerelem, szenvedély, a házaspár egyike többször akar nemi életet élni, mint a másik). A második legfontosabb az alkohol (magyarázott variancia: 15\%). A harmadik legfontosabb pedig a „racionális" konfliktus (magyarázott variancia: 13\%), amelynek elemei az eltérő gyermeknevelési módszerek, a szegénység (kevés pénz), valamint az, hogy a „férj/feleség túl sokat van távol otthonról”.

A nők körében inkább racionális konfliktusforrásokat találtunk. A középkorosztály (35-49 évesek) körében az érzelmi és a racionális veszekedés-faktor volt az erösebb, az italozás a 60 évnél idősebbek körében számított inkább problémának a házas(élet)társi kapcsolatban.

Azok körében, akik a legkisebb ( $17 \mathrm{~m}^{2}$ alatti) egy före jutó lakóterülettel rendelkeznek a háztartásban, inkább érzelmi és a racionális konfliktusforrásokat térképeztünk fel.

Fontos megemlítenünk, hogy a községekben igen erös az érzelmi motívumok és az ital által generált konfliktusforrások jelentősége a házastársak életében. A racionális konfliktusforrás viszont mindkét településtípusban inkább jelen van a válaszadók szerint.

A minta túlnyomó többsége elfogadja azt, hogy az alkoholfogyasztás és a szegénység teszi erőszakossá az embereket, és támogatja azt is, hogy a családon belüli erőszak elkövetése a negatív, szeretethiányos szocializációs mintához is köthető (az viselkedik így, akit gyerek korában bántottak) ${ }^{13}$.

A válaszadók családi veszekedéseinek mintegy egyharmadánál fordul elő fizikai eröszak, és mintegy kétharmadánál verbális erőszak ${ }^{14}$. A válaszadók szerint amíg a verbális erószak korosztályi szempontból nem jelent különbséget, a fizikai erőszak inkább a nyugdijasok és a középkorúak körében fordul elö. A közepes vagy kicsi lakóterülettel ${ }^{15}$ ( $28 \mathrm{~m}^{2}$ alatt) rendelkező válaszadók inkább verbális erőszakról számoltak be.

Fontos települési különbség, hogy fizikai eröszakról inkább a városokban élők számoltak be, a verbális erőszak viszont a községekben volt gyakoribb a vizsgált településeken (2. ábra).

A kérdezettek környezetében elöfordult házastársi bántalmazások átlagos száma 3,49. Fontos, hogy a minta közel $40 \%$-a tíznél kevesebb, de majdnem minden harmadik megkérdezett tíznél több ilyen esetről is be tudott számolni kérdezőinknek. Közel minden ötödik válaszadónk azonban nem tudott ilyen cselekményt feleleveníteni közvetlen környezetében. 
Jász Krisztina - Szarvák Tibor: A szakmaközi együttmüködés lehetöségei a szolnoki kistérségben egy családon belüli erőszak kutatás tükrében. - Tér és Társadalom, 21. 2007. 2. 67-84. p.

76 Jász Krisztina-Szarvák Tibor

TÉT XXI. évf. 2007 - 2

\section{2. ÁBRA}

A fizikai és verbális eröszak aránya a házastársi veszekedések során

(becslés százalékban)

The Proportions of Physical and Verbal Abuse During Quarrels between Married

Couples (estimate of percentage)

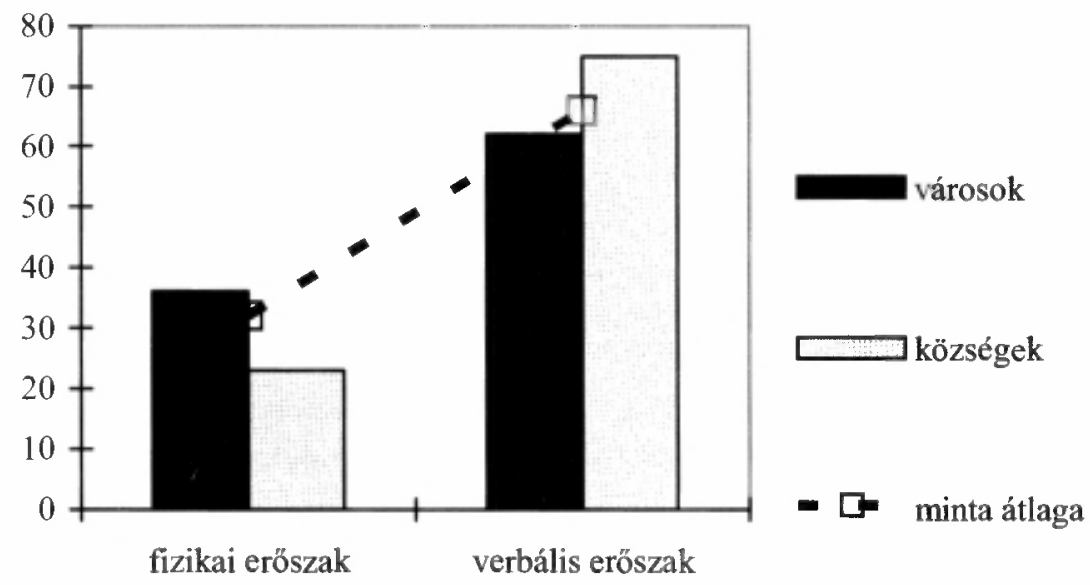

Forrás: Saját szerkesztés.

A családon belüli erőszak fogalmát kimerítő cselekedetek látenciájára (és a családi negatív minták átörökítésére) jó példa az, hogy válaszadóink harmada már gyermekkori családjában is fel tudott idézni a mostanihoz hasonló esetet, ső́t a minta több mint fele tud a rokonok és barátok körében is a családi, házastársi viselkedés során alkalmazott fizikai erőszakról.

A válaszadók szerint a feleség bántalmazása jóval gyakrabban fordul eló a házasságok, együttélések során (100 fokozatú skála átlagpontja: 61), mint a férj bántalmazása (100 fokozatú skála átlagpontja: 19). Ez a trend a nyugdíjas korú megkérdezettek körében fordul meg, akik a mintához képest gyakoribbnak gondolják a férfibántalmazást, mint a nők elleni fizikai agressziót. A fiatal felnött válaszadóink viszont magasabbnak vélik a házasságokban a nők sérelmére elkövetett cselekedeteket.

\section{A bejelentett bántalmazások száma, jellege, az elsö interjú hatása}

A felvétel tanúsága szerint a legtöbb esetben a bejelentő (a kérdezett) maga a családon belüli eröszak áldozata (62\%) illetve a bejelentö és gyermekei $(37 \%)$. Sok esetben (11\%) a bejelentỏ édesanyja. Viszonylag kevésbé jellemző - csupán 5\%-ban fordul elö - az, hogy csak a gyermekek legyenek áldozatok és a bejelentők.

A kérdezettek közül majdnem mindenki beszámolt fizikai bántalmazásról, amely néhány esetben gyermekelhanyagolással is párosult. 
Jász Krisztina - Szarvák Tibor: A szakmaközi együttmüködés lehetöségei a szolnoki kistérségben egy családon belüli erőszak kutatás tükrében. - Tér és Társadalom, 21. 2007. 2. 67-84. p.

A válaszadók közül először fơként családtagnak mondják el a bántalmazás megtörténtét. Minden harmadik válaszadó a rendörséghez fordul. De nem elhanyagolható ebből a szempontból a családgondozók és a barátok szerepe sem, hiszen a mintánk 6-6\%-a bennük bízik elsőként.

Fontos hangsúlyoznunk azt, hogy az eset elsö kommunikációjában a családgondozó szerepe fơként a községekben (lásd a társadalmi kapcsolati hálóról szóló 1. ábrát), a rendörségé pedig a városokban (nem elsősorban a megyeszékhelyen!) meghatározó. Jellemző még az is, hogy az 50 évnél idősebbek nem a családgondozóban bíznak meg elsőként. Érdekes, hogy a családgondozó és a rendőrség a közép és a fiatalabb korosztálynak jut eszébe elöször, az idősebbek körében inkább a családtagok segitenek. Mindez az iskolai végzettség tükrében úgy jellemezhetö, hogy a rendőri első segítség minden kategóriában általános, a családgondozói elsô segítség inkább a maximum 8 általánost végzettek körében jellemzó.

A bántalmazás kiderülése elött a kérdezettek több mint harmada hosszabb ideig együtt élt a problémával, több mint kétharmaduk számolt be néhány esetről a kiderülés elötti időszakból is. Jellemzően a 8 általánost végzettek türték inkább régóta az ilyen típusú eseteket.

A válaszadók arra a kérdésre, hogy hosszabb ideig miért nem tettek feljelentést, leggyakrabban a félelmet és a szégyent jelölték meg a fontosabb okok között. E két tényező átlagosan majdnem egyenlő mértékben esik latba. A társfüggőséget és azt a tényt, hogy nem tudták, kihez forduljanak, relative ritkábban jelölték meg.

A szégyen föként a középkorúak és a fiatalabb korosztály körében volt jellemző. Elsősorban az alacsony iskolai végzettségü nyugdíjas társadalmi csoport nem tudott hova fordulni problémájával. Körükben a félelem motivációja is erősebb volt. Érdekes, hogy a városokban említették inkább a félelem és a társfüggőség dimenzióját. A nemek tükrében azt mondhatjuk, hogy a női válaszadóknál a félelem, a szégyen és a társfüggőség is jellemzö, a férfiak körében azonban a „nem tudtam kihez fordulni" választípust rögzitettük leginkább (1. táblázat).

\section{TÁBLÁZAT}

A feljelentés halasztásának okai a nemek tükrében 100 fokozatú skálán (The Reasons of Postponing Denunciation According to Sex on a 100-grade Scale)

\begin{tabular}{lcccc}
\hline A kérdezett neme & Félelem & Szégyen & $\begin{array}{c}\text { Nem tudtam } \\
\text { kihez fordulni }\end{array}$ & $\begin{array}{c}\text { A társfüggóség } \\
\text { miatt }\end{array}$ \\
\hline Férfi & 29 & 33 & 52 & 38 \\
Nö & 66 & 66 & 42 & 45 \\
Összesen & 63 & 63 & 42 & 44 \\
\hline
\end{tabular}

Forrás: Saját szerkesztés.

A bántalmazás eseteinek kétharmada derült ki úgy, hogy a sértett vagy a családban más módon érintett személy jelentette az általa kompetensnek tartott személynek. A többi esetben ismerös (9\%) vagy idegen tett bejelentést $(7 \%)$, illetve az esetek ismét csak 7\%-ában a kérdezett számára nem derült ki, hogy kitöl származott a feljelentés. 
Jász Krisztina - Szarvák Tibor: A szakmaközi együttmüködés lehetöségei a szolnoki kistérségben egy családon belüli erőszak kutatás tükrében. - Tér és Társadalom, 21. 2007. 2. 67-84. p.

A bejelentés megtörténte körüli első intézményi kapcsolatot általában, mintegy $70 \%$-ban a rendőrség jelenti. Második helyen áll a családsegítő és gyermekjóléti szolgálat (7\%), valószínüleg azért, mert szerepet játszik a cselekedet kiderülésében. Más esetben a kérdezettek több intézménnyel egyszerre kerülnek kapcsolatba, amelyek között szerepel az említetteken kívül a gyámhatóság, háziorvos, védőnő, oktatási intézmény, egyház stb. Ezeken az intézményeken belül az első személyes kapcsolattartó 74\%-ban férfi, ami vélhetőleg arra vezethetỏ vissza, hogy ez az intézmény a legtöbb esetben a rendőrség.

$\mathrm{Az}$ ügyintézővel való első találkozás benyomásaként a kérdezettek harmada véli utólag, hogy segítőkész volt, közel ugyanilyen arányban mondják azt, hogy pozitív benyomást keltett, $15 \%$-uk találta megnyugtatónak a találkozást és megértőnek az ügyintézőt. Alig 10\%-uk élte meg kínosan a szituációt.

Kutatásunkban kíváncsiak voltunk arra, hogy milyen várakozás jellemezte a sértettet az elsỏ szakszerủ segítség idején. A válaszok jól tükrözik azt a lelki állapotot, amelybe ilyen sérelem esetén kerül(het) az ember. A nyitott kérdések között megtaláljuk a gyors eljárás igényét, a nyugodt, bizalmi beszélgetés kívánalmát, a probléma megszűnésének vágyát, az elkövető kiemelését, védelmet, biztonságot, megerösítést.

A válaszok a bizonytalanságot is visszatükrözik: ,nincs megfelelö segitség; azt vártam, hogy beleéljék a helyzetembe magukat; nyomatékosabb intézkedést, a bántalmazót figyelmeztessék, de ne vonják eljárás alá; a bántalmazó tartós eltávolítását, humánus eljárást a bántalmazóval". Itt kell azt megemlítenünk, hogy a válaszadók nem tudják eldönteni, hogy a feljelentéssel megzavarták-e vagy sem az erőszak elkövetöjét (100 fokozatú skála átlaga 51 pont $)^{16}$.

Ennek tükrében nem meglepő, hogy az igazságszolgáltatás szerveitöl válaszadóink leginkább a gyors eljárást, a gyermekekkel szembeni hangsúlyosabb megértést, a bántalmazó kiemelését, a határozottságot, az apa távoltartását (konkrét segítséget) és az emberi értékeket, nem pedig egyszerúen a törvények betartását várják.

A szociális szféra területén a családterápia, s a 'menedékház' hiányát, valamint a szociális munkások ritka látogatásait említették ${ }^{17}$.

A válaszadók azonban jellemzően elégedettek az ügyintézők munkájával. Indoklásukban kiemelik az ügyintéző kompetenciáját, segitőkészségét, türelmét, ugyanakkor kisebb részük arra mutat rá, hogy konkrét segítséget nem kapott, ismét egy kis részük szerint az ügyintéző érdektelen volt. Hasonló kritikák (pl. elvitték, de rövid időn belül visszaengedték a bántalmazót, kis idöre fékezte meg az agresszort, semmit nem értem el, hogy kihívtam a rendöröket) megfogalmazódtak, de összességében az elégedetlenek aránya nem éri el a 15\%-ot, és ezek közül a teljesen elégedetlenek aránya $8 \%$.

Az alábbi tulajdonság-párokból újra az elégedettség tükröződik vissza. A válaszadók ugyanis föként a segítőkész, a megnyugtató, a kulturált, a megértő és a hozzáértö jelzőket társították az ügyintézö tevékenységéhez. Érdekes, hogy a nőpártiférfipárti kategóriák már inkább megosztották a megkérdezetteket.

A válaszadó ügyének első hivatalos szereplöjét és a tulajdonság-párok értékét látva azt tapasztaljuk, hogy a rendörség, a családsegitő és a gyermekjóléti szolgálat értékei 
Jász Krisztina - Szarvák Tibor: A szakmaközi együttmüködés lehetöségei a szolnoki kistérségben egy családon belüli erőszak kutatás tükrében. - Tér és Társadalom, 21. 2007. 2. 67-84. p.

TÉT XXI. évf. 2007 — 2 A szakmaközi együttmüködés lehetőségei a ... 79

között nincs matematikai különbség. Azt gondoljuk, hogy az intenzitásbeli eltérések különösen a családon belüli erőszak problémakörében különösen fontos professzionális segitői attitüdök (problémaérzékenység, tevékenység, megértés, segitőkészség) körében mutatkoznak meg, amelyek véleményünk szerint a felsőfokú képzésben és a munka világában tapasztalható eltérő szocializációra vezethetök vissza.

\section{Az intézmények munkájának értékelése}

A családon belüli eröszak kapcsán az emberek természetszerüleg több intézménnyel is kapcsolatba kerülnek. A válaszok alapján a kérdezettek túlnyomó többsége, 94\%-a került segítő kapcsolatba a rendőrséggel, 54\%-uk a családsegítő és gyermekjóléti szolgálattal, mintegy harmaduk a bírósággal, ügyészséggel, ismét egyharmaduk a háziorvossal, de még sok más intézménnyel, így a közoktatási intézmények képviselőivel (gyermekvédelmi felelösök, bölcsỏde, óvoda) is jellemzỏ ez az interakció.

Alapvetően azonban azt látjuk, hogy a rendőrség, a szociális és egészségügyi szféra és az igazságszolgáltatás az a terület, amelyek képviselőivel a kistérség lakói leginkább találkoznak ügyük intézése során. A 2. táblázatból az is jól látszik, hogy a térségben nincs olyan civil szervezet, amely a problémával kiemelten foglalkozna.

\section{TÁBLÁZAT}

A kérdezettek száma az egyes intézményekkel való kapcsolatba kerülésük tükrében (The Number of those Questioned Based on the Institation Contacted)

\begin{tabular}{lc}
\hline & Elemszám \\
\hline Rendörség & 104 \\
Családsegító és gyermekjóléti szolgálat & 61 \\
Háziorvos & 36 \\
Bíróságok, ügyészség & 34 \\
Védőnő & 19 \\
Gyámhatóság & 18 \\
Ügyvéd & 15 \\
Szabálysértési hatóság & 13 \\
Iskolai gyermekvédelmi felelősök & 13 \\
Közoktatási intézmények & 12 \\
Bölcsőde, óvoda & 6 \\
Egyház & 2 \\
Egyéb civil szervezet & 1 \\
Jogvédỏ iroda & 1 \\
Esélyek Háza Esélyegyenlőségi Hálózati Iroda & 1 \\
\hline
\end{tabular}

Forrás: Saját szerkesztés.

A válaszadók a rendőrséget (44\%-uk) és a családsegítỏ és gyermekjóléti szolgálatot (27\%-uk) itélték a leghatékonyabbnak. A többi intézmény (bíróság, ügyészség, ügyvéd, háziorvos, gyámhatóság, iskolai gyermekvédelmi felelősök, közoktatási intézmények, szabálysértési hatóság) hatékonysága már kevésbé kimagasló. A Szolnokon élök majdnem kétharmada a rendőrséget, $\mathrm{s}$ alig ötödük a családsegítỏ és 
Jász Krisztina - Szarvák Tibor: A szakmaközi együttmüködés lehetöségei a szolnoki kistérségben egy családon belüli erőszak kutatás tükrében. - Tér és Társadalom, 21. 2007. 2. 67-84. p.

gyerekjóléti szolgálatot, a tágabb vonzáskörzetben élök viszont a két intézményt egyformán tartották kiemelkedönek.

Mindez a városok-községek tükrében már puhább eltéréseket eredményezett. Az urbánus településeken $47 \%$-ban a rendôrség, $26 \%$-ban pedig a szociális ellátás intézménye volt meghatározó az ügy kezelésében. A községekben pedig a válaszadók 37\%-a ,voksolt” inkább a rendőrségre, majdnem egyharmaduk pedig a családsegítő szerepét hangsúlyozta.

\section{A családon belüli eröszak problémájának kezelése}

A beavatkozás összességében pozitív irányba változtatta a kérdezettek közérzetét, körülményeit. Leggyakrabban a hangulat, az érzelmek (100 fokozatú skálán 70 pont) és az önbizalom (100 fokozatú skálán 68 pont) pozitív változását és a társas kapcsolatok felélénkülését (100 fokozatú skálán 65 pont) emelték ki. Érdekes, hogy ezek az értékek a férfiak körében alacsonyabbak maradtak, illetve az érettségizett vagy diplomás válaszadóknak erőteljesebben növekedett az önbizalma és pozitívabban változott a hangulata. A megkérdezettek nagy többsége találkozott rendőrrel illetve családsegító szakemberrel az ügye kapcsán, a többi szakmaterület megfelelő szakembereivel való kapcsolat sokkal kevésbé jellemző ${ }^{18}$. Leghatékonyabbnak is ezeket a szakmákat tartják a felsoroltak közül. A rendőr munkáját $38 \%$ érezte a leghatékonyabb segítségnek, míg a családsegitőét minden negyedik válaszadónk. Kiemelkedett a vélemények szerint még az ügyészi és a bírói tevékenység is. A válaszadók a rendör-családsegítö-pszichológus hármas segítōi teamet gondolnák a legjobbnak a családon belüli erőszak kezelésére. A megkérdezettek 27, 20, illetve 14\%-ban jelölték meg ezeket a foglalkozásokat.

Ahhoz, hogy hatékony legyen a családon belüli erőszak prevenciója és ,gyógyítása" legfontosabbnak a családsegító és gyermekjóléti szolgálatok, a rendőrség és a szülök közös együttmüködését tartják válaszadóink, de lényegesnek minősítik a gyámhatóság, az iskolai gyermekvédelmi felelösök, a bíróságok és ügyészségek bevonását is.

A települési különbségek kapcsán lényeges, hogy a háziorvosnak inkább a városokban, a védőnői hálózatnak inkább a községekben szánnának nagyobb szerepet válaszadóink. Feltehetően a gyakoribb interakciós mezöhöz köthető az a jelentős különbség is, amely a városokra (s különösen Szolnokra) jellemző a civil szervezetek, a jogvédő iroda és az Esélyek Háza említése kapcsán (3. táblázat).

A klasszikus segítői hálóhoz kapcsolódó intézmények mellett a média is sokat segithet abban, hogy ezek az esetek ismertté váljanak ${ }^{19}$. A televízió és a rádió, valamint a nyomtatott sajtó hatását fơként a fiatalabbak vallják (100 fokozatú skála átlaga 84 pont), de a minta egészében is pozitív hatással bír a média (100 fokozatú skála átlaga 70 pont). 
Jász Krisztina - Szarvák Tibor: A szakmaközi együttmüködés lehetöségei a szolnoki kistérségben egy családon belüli erőszak kutatás tükrében. - Tér és Társadalom, 21. 2007. 2. 67-84. p.

TÉT XXI. évf. 2007 a 2 Aszakmaközi együttmüködés lehetóségei a ... 81

\section{TÁBLÁZAT}

A családon belüli eröszak kivánt segitỏi hálója 100 fokozatú skálán

(The Desirable Network of Helpers to Victims of Domestic Violence on a 100-grade Scale)

\begin{tabular}{lcccc}
\hline & Szolnok & Városok & Községek & $\begin{array}{c}\text { Minta } \\
\text { átlaga }\end{array}$ \\
\hline Szülök & 88 & 80 & 89 & 83 \\
Rendörség & 89 & 85 & 83 & 84 \\
Háziorvosok & 68 & 62 & 55 & 60 \\
Védónöi szolgálat & 68 & 59 & 68 & 62 \\
Családsegítő és gyermekvé- & 87 & 83 & 88 & 85 \\
delmi szolgálat & 66 & 59 & 58 & 59 \\
Bölcsőde, óvoda & 69 & 62 & 66 & 63 \\
Iskola, tanárok & 75 & 70 & 83 & 74 \\
Iskolai gyermekvédelmi & 55 & 48 & 70 & 55 \\
felelősök & 60 & 53 & 47 & 51 \\
Polgármesteri hivatal & 78 & 69 & 63 & 67 \\
Ügyvédek & 58 & 48 & 34 & 44 \\
Bíróságok, ügyészség & 41 & 32 & 28 & 31 \\
Civil szervezetek & 87 & 79 & 77 & 78 \\
Egyház & 77 & 70 & 57 & 66 \\
Gyámhatóság & 60 & 49 & 40 & 46 \\
Jogvédő iroda & & & & \\
Esélyek Háza Esélyegyenlöségi & 60 . & & \\
Hálózati Iroda & & &
\end{tabular}

Forrás: Saját szerkesztés.

\section{A családon belüli eröszak szankcionálása}

A válaszadók a távoltartást tartják a legmegfelelöbb büntetésnek (100 fokozatú skálán 84 pont), de a családterápiára kötelezést (100 fokozatú skálán 77 pont) is gyakran megjelölték kívánatos eszközként, a szabadságvesztés büntetést az elóbbieknél lényegesen kevésbé gondolják megfelelö büntetésnek (100 fokozatú skálán 67 pont), de még így is inkább támogatják ezt a szankcionálási formát, mint elvetik. A szabadságvesztést és a családterápiát elsősorban a férfiak, a távoltartást a nỏk tartják fontosabbnak. Ủgy tủnik, hogy amíg a szabadságvesztés és a családgondozás professzionálisabb típusa között nincs különbség a települések között, a távoltartás a városokban (különösen Szolnokon) élö megkérdezettjeink támogatását „élvezi”. Ennek a formának az alkalmazását értékelné inkább az érettségizett vagy diplomás válaszadói kör is ${ }^{20}$.

Fontos ugyanakkor, hogy válaszadóink a büntetés szigorítását tartják a legcélravezetöbb eszköznek a családon belüli erőszak visszaszorítására, persze fontosnak ítélik a segítő környezeti háló terjesztését ugyanúgy, mint a rendőri ellenörzések számának emelését. Az elkövetỏ nevének megismertetését a lakókörnyezetben a 
Jász Krisztina - Szarvák Tibor: A szakmaközi együttmüködés lehetöségei a szolnoki kistérségben egy családon belüli erőszak kutatás tükrében. - Tér és Társadalom, 21. 2007. 2. 67-84. p.

kérdezettek kevésbé tartják használható eszköznek a családon belüli erőszakkal szemben $^{21}$. Véleményünk szerint ez is utal a hazai közösségek rossz állapotára, illetve ezzel párhuzamosan a közösség-építés települési szintü megvalósitására. Érdekes ellentmondás, hogy a válaszolók a családon belüli erőszak egyes megnyilvánulási formáival szemben meglehetősen toleránsak, az elkövető megbüntetését sem szorgalmazzák, ellenben bizonyos magatartásokat sokkal szigorúbban büntetnének. Leegyszerüsítve: vagy nem büntetnének, vagy igen szigorúan.

Lényeges azonban, hogy ez utóbbi elemet a községekben élök ${ }^{22}$ (valószínüleg a tradíciókhoz, a közösség hatásához visszakapcsolódva) különösen lényegesnek tartják. Tekintettel arra, hogy az átlagpolgár nem ismeri a jelenlegi törvényi szabályozást, így ezek a vélemények nem tekinthetök egzaktnak, hiszen nem tesznek különbséget a családon belüli eröszak egyes megnyilvánulási formái között.

\section{A kutatás lehetséges felhasználási területei}

A kutatás (és tágabban a pályázati program) társadalmasitásának szakaszában hangsúlyozmunk kell azt a szakmaközi együttmüködést, amely érzékelhetően erősítette a rendőrkapitányság szakemberei és a szociális munkások közötti együittmüködést, javította az intézmények közötti kommunikációt. Kialakultak azok a személyes kapcsolatok, amelyek elengedhetetlenek a gyors és összehangolt közös cselekvéshez.

Társadalompolitikai és területi nézöpontból azt emelhetjük ki, hogy mintánk egyik legmélyebben gyökerező problémája a kapcsolati háló gyengesége. Mindenképpen hasznos volt tehát az a kutatási elképzelés, amely a professzionális segitőket „kérdezőbiztosként" is szerepeltette. Az adatok azt mutatják, hogy ebben, a kliensi oldalról erősen bizalmatlan légkörben a professzionális segitőtől kapott szolidaritás és stratégia meghatározó a stabilabb jövőkép kialakitásában. A vidéki térségek helyzetét jól mutatja az, hogy a tömegkommunikációs információs forrásokból viszonylag ismertek a családon belüli erőszak hatásainak csökkentéséért küzdő szervezetek; helyben azonban nincsenek ilyen közvetlenül elérhető civil támogató lehetőségek.

Összességében megfogalmazhatjuk azt, hogy a kirekesztettség (érzésének) csökkentése, a társadalmi jelzőrendszer újraszervezése a professzionális segitói csoportok feladata lehet. Különösen fontos feladat lehet ez a városokban (a szolnoki kistérségben), ahol azt tapasztaltuk, hogy a professzionális segitő hatása a községekben az erősebb.

A kutatás eredményei közül kiemelendő az, hogy a rendőri beavatkozást többnyire hasznosnak, de nem elégségesnek tartják, és válaszadóink egy rendör - családgondozó - pszichológus teamet részesítenének előnyben.

Fontos mentális attitüdöt jelent, hogy az elkövetöt az áldozatok többsége nem megbüntetni, hanem megváltoztatni akarja, $\mathrm{s}$ a megoldások tekintetében eltér a nök és a férfiak véleménye.

Lényeges még az is, hogy az eredmények ismeretében a kapitányság vezetése úgy döntött, fokozottabb mértékben nyit a segítő szakmákat képviselő civil szervezetek felé, már az eljárások kezdeti szakaszától bevonja öket az áldozatok lelki gondozásába, illetve lehetőséget biztosít az agresszorral történő kapcsolatfelvételre. 
Jász Krisztina - Szarvák Tibor: A szakmaközi együttmüködés lehetőségei a szolnoki kistérségben egy családon belüli erőszak kutatás tükrében. - Tér és Társadalom, 21. 2007. 2. 67-84. p.

TÉT XXI. évf. 2007 - 2 A szakmaközi együttmüködés lehetöségei a ...

\section{Jegyzetek}

${ }^{1}$ A kutatás lebonyolításában köszönjük Bozorádi János rendőr alezredes segítségét (Szolnoki Rendőrkapitányság Bủnmegelözési és Értékelő Alosztály). A munkához anyagi hátteret az $\mathrm{OBmK}$ által kiírt és Szolnok Megyei Jogú Város által elnyert pályázat jelentett. Megjegyezziuk, hogy a Szolnok Városi Rendőrkapitányság illetékességi területe két településsel (Tiszaföldvár, Szajol) bövebb, mint a 244/2003. (XII.18.) kormányrendeletben meghatározott szolnoki KSH kistérség, ahová 17 település tartozik.

A projekt minden anyagát A családon belüli erőszakról egy kutatás tükrében (Szerzők: Jász KrisztinaBozorádi János-Szarvák Tibor) címũ kiadványban olvashatják el. Jelen tanulmány csak az empirikus felmérés bemutatására fókuszál.

${ }^{2}$ A feldolgozás során több változó-összevonást is használunk, valamint az eredményeket több alkalommal százfokozatú skálán közöljük. A százfokozatú skála értékei minden esetben csak az értékelhető válaszokra vonatkoznak a következök szerint: a százas érték azt jelenti, ha minden válaszoló a maximális, nulla, ha minden válaszoló a minimális pontszámot adná. A százfokozatú skálákon az ötven pont alatti érték negativ véleményt (bizalmatlanságot, ellenszenvet stb.), míg az ötven pont feletti érték pozitiv véleményt (bizalmat, rokonszenvet stb.) jelez.

${ }^{3}$ Jelen tanulmányban a kutatás után, szolnoki családsegitőkkel készült prominens interjúkból is idézünk. Így fontos rơgzítenünk a módszerröl is a véleményüket: a kérdezés során a sértetteknek vissza kellett emlékezni az eseményekre, illetve sokan nem akarták kitölteni, mert féltek.

${ }^{4}$ Egyes amerikai és európai vizsgálatok azt mutatják, hogy a férfi - ha a családon belüli eröszak áldozata is - sokkal alacsonyabb valószinúséggel jelenti be a cselekményt, mint a nő. Különbőző módszertani elemek (pl. telefonos reprezentativ minta) alkalmazása során azonban kiderült, hogy a férfi-áldozatok száma a vártnál jóval nagyobb. Ranschburg Jenő szóbeli közlése.

${ }^{5}$ A szakirodalmi adatok szerint a férfiak által elkövetett erőszak esetén jellemző az alacsonyabb státusz. A fordított helyzetre azonban (amikor a nö az elkövetö) már egyáltalában nem. Ranschburg Jenó szóbeli közlése.

${ }^{6}$ Érdekes összevetést jelenthet egy 2005-ben végzett, Jászberény felnött lakosait érintỏ vizsgálat, amelybỏl kiderült, hogy a Jászság központjában gondjaik, problémáik megoldásában leginkább a családra, szükebb rokonságra (100 fokozatú skála átlaga: 85 pont), barátokra (100 fokozatú skála átlaga: 61 pont), szomszédokra (100 fokozatú skála átlaga: 52 pont) számitanak, a szociális segitők említése 100 fokozatú skálán 32 pont volt (Szarvák 2005)

${ }^{7}$ A bizalom - más megfogalmazásban: partnerség - kapcsolathálóját (Utasi 2002, 30) személyközi kapcsolatokban az ơnzetlenség, az altruizmus jellemzi.

${ }^{8}$ Szolnokon 2000-ben a belvárosban 74, a Zagyván túli területeken 68, a Pletykafaluban 63 pontra értékelték probléma esetén a családi segitség szerepét (Murányi-Szoboszlai 2000).

${ }^{9}$ A kapcsolatokkal azonban mindent el lehet érni - vélik válaszadóink ( 100 fokozatú skála átlaga 82 pont).

${ }^{10}$ A férj sértő, megalázó dolgot mond feleségének.

${ }^{11}$ Szolnokon ez az érték 88 pont. A minta átlaga 92 pontra minősítette a kérdés fontosságát.

12 Az eljárás arra alkalmas, hogy több változóból „kiszürje” azok közös komponensét. A látszólag fuiggetlen állításról alkotott véleményekből az eljárás során kirajzolódik az az attitủd jellegủ kognitiv beállítódás, amelyről a válaszadó tudatosan esetleg nem is tud választ adni, de amely ott van minden egyes válasza mögött. $\mathrm{A}$,közös részt” tartalma alapján nevezhetjuk el. $\mathrm{Az}$ analizis során minden válaszoló kap egy súlyszámot (úgynevezett faktor-score-t), amely alapján a kérdezettek csoportjai is jellemezhetők. A fỏkomponenseken belüli sorrendet a kialakításában részt vevő változók faktorsúlya alapján ismertetjük, feltüntetve a magyarázott varianciát is.

13 Érdekes azonban, hogy a hagyományos ,patriarchális" szemléletmód, a hatalom, az irányítás igénye ennél a kérdésnél nem köszön vissza.

${ }^{14}$ Becsülje meg azt, hogy a veszekedések tơbbségében milyen arányban fordul elö Önöknél fizikai erőszak és verbális erőszak.

A segítők szerint egyik esetben sem beszélhetünk tisztán fizikai bántalmazásról, hiszen ez párosul az érzelmivel is.

${ }^{15}$ Egy före jutó érték. Az átlagos háztartásnagyság: 3,38 fỏ. 
Jász Krisztina - Szarvák Tibor: A szakmaközi együttmüködés lehetöségei a szolnoki kistérségben egy családon belüli erőszak kutatás tükrében. - Tér és Társadalom, 21. 2007. 2. 67-84. p.

${ }^{16}$ Megiegyezzük, hogy a fiatal felnőtt válaszadók körében ez az érték 100 fokozatú skálán 71 pont, ami a feljelentés szankcionáló hatását, a községekben gyakori 45 pont pedig annak hatástalanságát jelenti.

${ }^{17}$ A családon belüli erószak esetében nem csak egy ember a kliens, hanem az egész család. Itt a kettős esetvezetés és a családterápia a célravezetô módszer - hangsúlyozták a szolnoki családsegítők.

${ }^{18}$ Orvossal minden harmadik, pszichológussal, szociális munkással minden ötödik, védőnővel pedig minden tizedik sértett találkozott ügyének menete során.

${ }^{19}$ A családsegítők szerint a legfontosabb az volna, ha a családon belüli eröszak kezelését is a gyökereknél kezdenénk megoldani. Ez azt jelenti, hogy az iskolában tartani kellene a családon belüli erőszakról olyan felvilágosító órákat, mint a drogokkal vagy a továbbtanulással kapcsolatban.

${ }^{20}$ A maximum 8 általánossal rendelkezők inkább a szabadságvesztést támogatnák.

${ }^{21}$ A családsegítök szerint a jogi megközelítés rossz, egyrészt, mert a nő félhet, hogy ha elárulja a férje tetteit, akit szeret, akkor elveszítheti őt, hiszen börtönbe csukhatják. Ezen kívül az elkövető és a családja bosszút állhatnak a sértetten. Talán az alternatív büntetési módok lennének a megfelelök.

${ }^{22}$ Főként a 60 évnél idősebb válaszadóink.

\title{
Irodalom
}

Nagy E. (2005) Ki a gyengébbik nem? Szakdolgozat, SZIE Jászberényi Főiskolai Kar Szociálpedagógia Tanszék, Jászberény.

Ranschburg J. (2006) A meghitt eröszak. Saxum Kiadó Bt., Budapest.

Murányi I.-Szoboszlai Zs. (2000) Résztársadalmak. Azonosság és különbözőség a szolnoki városrészek társadalmában. Kézirat. MTA RKK ATI Szolnoki Társadalomkutató Csoport, Szolnok.

Szarvák T. (2005) Szociális és mentális térkép Jászberényben - Pethő L. (szerk.) Jászsági Évkönyv. 149-159. o.

Utasi Á. (2002) A bizalom hálója. Mikrotársadalmi kapcsolatok, szolidaritás. Új Mandátum Kiadó, Budapest.

\section{THE POSSIBILITIES OF INTERPROFESSIONAL COOPERATION IN THE MICRO-REGION OF SZOLNOK IN CONNECTION WITH A RESEARCH ON DOMESTIC VIOLENCE}

\author{
KRISZTINA JÁSZ - TIBOR SZARVÁK
}

Observing the topic of domestic violence official helpers and reserchers face the following dilemmas:

Is there a definition for domestic violence at all which is valid under all sorts of circumstances? Where are the borders of private sphere? Is there any right for an outsider to intrude domestic affairs although with the acquiescence of one or the other party in many cases? If there is then when and in what way? Do the different behaviours within the category of domestic violence need separate regulation or the present day summary offence regulations and the statements of the Penal Code are suitable? Who is the victim and who is the aggressor? Or the latter is a potential victim, too?

We should have to find legal as well as practical solutions in accordance with the constitutional processes.

In 2005, the leadership of the Central Police Department in Szolnok have decided to act against this phenomenon as far as possible although at that time they had no exact knowledge about the measure of the problem. Special regulations against domestic violence did not come into force despite all the debates about this question, that is why the police felt itself alone with the struggle with this phenomenon without any legal weapon. 